\title{
NON-COST STANDARDS IN RATE MAKING
}

\author{
ROBERT L. HALE
}

Generally speaking, rates fixed by a commission, to be valid, must be sufficient to yield a fair return on the "fair value" of the company's property. The precise meaning of this phrase will not be discussed in this paper. Not only must the rates, as an aggregate, yield this fair return; but, generally speaking, the rates fixed on any particular class of the service must yield a fair return. Thus, when the legislature of Nebraska fixed intrastate rates which appeared to the Supreme Court to be insufficient to yield a fair return, the constitutionality of the act was not saved by the fact that in spite of these rates, the railroads were able to earn a fair return out of all their traffic, including that in other states and interstate. ${ }^{1}$ Moreover, the fact that the total intrastate traffic yielded a sufficient return did not prevent intrastate rates for the carriage of coal from being held unconstitutional, when the coal rates yielded little or nothing above the out-of-pocket cost of carrying that coal. ${ }^{2}$ Yet classifications are permissible that may be broad enough to include at the same rate individual services the costs of which may vary; "the company cannot claim the right to earn a net profit from every mile, section, or other part into which the road might be divided, nor attack as unjust a regulation which fixed a rate at which some such part would bo unremunerative." 3 But this does not seriously modify the general proposition laid down in the North Dakota case, ${ }^{4}$ for in that very case Justice Hughes remarked that the state's authority is not "hampered by the necessity of establishing such minute distinctions that the effective exercise of the rate-making power becomes impossible. It is not bound to prescribe separate rates for every individual service performed, but it may group services by fixing rates for classes of service."

There are, however, more serious qualifications to the doctrine that each class of rates must pay its own cost plus fair return. ${ }^{3}$

\footnotetext{
${ }^{1}$ Smyth v. Ames, 169 U. S. 466, 540-542, 18 Sup. Ct. 418, 431, 4302 (1898).

2 Northern Pacific Ry. v. North Dakota, 236 U. S. 585, 35 Sup. Ct. 429 (1915).

${ }^{3}$ St Louis \& San Francisco Ry. v. Gill, 156 U. S. 649, 15 Sup. Ct. 484 (1895).

+ Supra note 2.

- Such a rate will be referred to hereafter as "the cost rate." The torm is convenient though not accurate, unless the fair return is calculated on cost rather than on the hodge-podge known as "fair value." Moreover, the term assumes that there is such a thing as "the cost" of one class of transportation as distinct from that of the other classes. Such an assump. tion is believed to be false. Certain of the costs can be segregated and said, with accuracy, to be caused by the class of traffic in question. Theso
} 
An order to run a new train, although it would have to be run at a loss, was held valid where it appeared that "adequate remuneration would result from the general operation of the rates in force, even allowing for any loss occasioned by the running of the extra train in question." : An order to continue the operation of a line of a traction company was also held valid, although it appeared impossible to continue it without loss, where, from the state of the evidence it did not appear that the company would obtain less than a fair return from its total business." On the other hand, an order to continue running certain trains was held invalid, partly on the ground that the railroad was on the verge of insolvency. ${ }^{3}$ It seems to follow from these cases that there may be circumstances in which service at rates below cost may be required constitutionally, particularly if the loss is made up by rates above cost on other services; but that the mere fact that the less-than-cost rates are balanced by other rates at more than cost, is not sufficient to justify the former; and further, rates will be considered to be less-than-cost, even if they yield something more than out-of-pocket costs.

In this paper I shall not attempt to discuss at any length the particular grounds of social expediency which have been held to justify rates below or above cost; but merely to point out some consequences of the Supreme Court's recognition that there may be such grounds. Before passing on to grounds justifying, or even requiring as a constitutional matter, rates above cost, it is well to enumerate two other circumstances in which rates below: cost, as that term is defined in the North Daliota case, may be justified.

The principle of making concessions to traffic that "will not bear" a higher rate is familiar. These concessions, however, do not require rates on other traffic above cost, in any realistic defi-

are the so-called "out-of-pocket" or "separable" costs. There remain, however, the joint costs, which must be incurred ir any trafic at all is to bo taken, but which are not added to by any one class. These must be met by the total trafic, and the rate making body can, within limits, and must apportion them to the various classes in some manner. But the choice of the precise measure of apportionment is necessarily "arbitrary" in the sense that it is not a reflection of some objective fact. The ratemaking body must either make the apportionment blindly, or else base it on grounds of social policy concerning the relative desirability of the cheapening of this rather than of that class of service. However, for purposes of discussion, it will be assumed in the text of this article that there is such a thing as "the cost" of each class of traffic.

6 Atlantic Coast Line R. R. v. North Carolina Corp. Commiesion, 206 U. S. 1, 27 Sup. Ct. 585 (1907).

T Puget Sound Traction, L. \& P. Co. v. Reynolds, 244 U. S. 574, 37 Sup. Ct. 705 (1917).

8 Mississippi R. R. Commission v. Mobile \& Ohio R. R., 24d U. S. 238, 37 Sup. Ct. 602 (1917). 
nition of the term, in order to avoid a loss to the company. In making these concessions, the distinction between out-of-pocket and joint costs, so contemptuously dismissed by Justice Hughes in the North Dalkota case, must be borne in mind. If a particular class of traffic can not be secured except at a rate lower than the out-of-pocket cost of carrying that traffic, then the concession of that rate does indeed inflict a loss on the company, unless the burden on other customers is higher than it otherwise need be. The out-of-pocket cost (by definition) would be saved if that class were not carried, while the gross revenue lost by not carrying it would be less than the saving. But if, by making a concession in the rate, and only by making the concession, a class of traffic can be secured which will contribute something, however little, above its out-of-pocket costs, then the concession lightens rather than adds to the burden that must be imposed on the remaining traffic if the company is to be saved from loss. Failure to obtain the traffic would save only its out-of-pocket costs, and would sacrifice a revenue somewhat more than this saving. If the company can obtain this revenue, then part of the joint costs can be defrayed by it, and a smaller part of them than otherwise need be met by the rates charged to the remaining traffic. By definition the joint costs are those which would remain the same whether this particular traffic were carried or not. Hence it is presumably a benefit to the class discriminated against, as well as to the class favored, to establish this particular kind of less-thancost rates. ${ }^{8 a}$

8a It is true that if "cost" be defined as a mathematical division of joint costs among all the traffic (plus of course the out-of-pocket or separable cost of each), then the classes not favored by the concession will be paying more than their "cost"; but this is merely because the division that would be made if the favored traffic were eliminated would make the supposed "cost" to the unfavored traffic higher than it appears to be when the rates are such as to bring the favored traffic into the accounting. This can be made clearer by an oversimplified illustration. Suppose there are no out-of-pocket costs, and the total costs are, say, one hundred. Fifty units of traffic $A$ will be taken, even if the rate is as high as two per unit; no more units of $\mathrm{A}$ will be taken under any rate. Twenty-five units of traffic $B$ will be taken if a rate of one per unit is charged for it, but it will not move at a higher rate. Now if rates are fixed at one per unit for $B$ and one and a half for $A$, the company will meet its entire cost; but the nominal cost for each unit of either kind is one hundred divided by seventy-five, or one and a quarter; hence $A$ is nominally paying more than cost, by reason of the concession to $B$. But if no concession were made to $B$, there would be no units of $B$ to consider, and the cost per unit of $A$ would be one hundred divided by fifty, or two. And a rate of two would be required. But each unit of $A$, while in this case paying no moro than cost, would be paying more than if the concession were made, though in that case paying more than the nominal cost. The concession enables a reduction to be made in the rate charged A, although the "cost" falls even more than does the rate. 
There is another class of cases where a rate below cost may be tolerated. That is when predictions as to the earnings liliely to be yielded by a particular schedule of rates prove inaccurate. In these cases there may be delays during which the rates lawfully in force yield less than a fair return. This of course gives the company grounds for insisting on a revision of the rates upwards, as a matter of constitutional right; but until the revision is made, the customers are entitled to be served at the rates temporarily in force.

Let us next turn to rates higher than cost. Wre have seen that the requirement of specified service at rates below cost may depend for its validity, in part at least, on whether the company is making up the deficiency out of other branches of the traffic. If it is, rates on that other traffic must of mathematical necessity exceed cost. Would it be constitutional to reduce them? The question was raised in Groesbeck v. Dututh, S.S. \& A. Ry., affirming a decree of the District Court which enjoined the enforcement of a two-cent passenger law on the ground that it was confiscatory. The officials of the state alleged that the district judge committed certain specific errors in his calculations, one of which is dealt with by Justice Brandeis, spealing for the entire court, as follows: ${ }^{10}$

"Fourth: The further contention is made that the sleeping car, parlor car and dining car services should be treated as separate operations; that they should be charged with their proportion of specific and general expenses but credited only with the amounts received from charges for the specific service; and that no part of the apparent loss on these services should be talien into consideration in determining whether the two-cent fare is confiscatory. In support of this contention it is urged that these services were voluntary; that the law (Michigan Public Acts of 1875, No. 38) permits railroads to make special charges for these services 'in addition to the regular passenger fares allowed by law, and that travellers in day coaches must not be allowed to suffer because a railroad fails to make these services compensatory. On American railroads of importance these services have been well-nigh universal for more than a generation; and the charges for them are substantially uniform throughout the country. It would be practically impossible, as it would be obviously unwise, for a railroad like the plaintiff's either to discontinue the services or to increase the charges to cover the cost of the particular service on its line. It is inconceivable that the legislature of Michigan should have intended in enacting the two-cent fare law to deny to its citizens these customary facilities; and for the purpose of determining whether the act is confiscatory the passenger service including these facilities must be treated as a whole. The fact alleged that these facilities are used mainly by interstate travellers is immaterial."

9 250 U. S. 607, 40 Sup. Ct. 38 (1919).

${ }^{10}$ Supra note 9, at 613-614, 40 Sup. Ct. at 41. 
It seems, then, that a rate above cost may be required on one service to enable the company to make up the losses it would otherwise incur in rendering certain other essential services at a rate below cost.

Rates above cost may also occur (although not constitutionally required) in other circumstances. One instance is analogous to one already noted in the case of rates below cost-namely the case of erroneous prediction. A rate may be fixed for the purpose of yielding to the company a particular "fair return," and then turn out to yield much more. This fact may result in an eventual reduction, but until that time it is the lawful rate.

Then again, a rate may be tolerated, or even required, above cost, to avoid certain forms of injurious competition. In $R e$ Street Railroad Rates, ${ }^{11}$ the District of Columbia Commission fixed uniform fares for the two companies operating in Washington, although it recognized that this would give one of them more than a fair return. To reduce its fare, in the Commission's opinion, would tend to ruin its competitor, which could not afford to charge a lower fare. In another case the Public Service Commission of the state of Washington, acting under the authority of a statute, actually ordered a tramp steamer to increase its rates to a parity with those of the regular shipping company with which it competed in Puget Sound, although the lower rates which the tramp had been charging yielded it a fair return. ${ }^{12}$ Some of the concessions already discussed, in favor of traffic which will not movo otherwise, even though beneficial to other traffic on the railroad which makes the concession, may be equally injurious to the railroad with which it competes and to all the customers of the latter road. That road may in turn have to reduce the rate for that traffic still more. This sort of cut-throat competition is recognized as beneficial to no one in the long run. By the Act of 1920 Congress conferred on the Interstate Commerce Commission power to prevent it by establishing minimum as well as maximum rates. ${ }^{13}$ The power might conceivably be used, as the similar power was used by the Washington Commission in the case of the tramp steamer, to force one railroad to charge a rate above cost on certain traffic.

There may be cases where a rate is sufficiently remunerative, but the service is overcrowded and hence inferior to what it might be. An increase in the rate may reduce the crowding, by discouraging unnecessary use of the service, and may at the same

11 PUB. UTH. REP. (D. of C.) $1921 \mathrm{E}$, at 13.

12 Public Service Commission v. Garfield, Pub. UtiL. Rep. (Wash.) 1016 $B$, at 835 .

13 For some of the possibilities following the conferring of this powor, see the remarks of Justice Brandeis in United States v. Illinois Central R. R., 263 U. S. 515, 525, 44 Sup. Ct. 189, 193 (1924). 
time increase the company's return (the higher rate more than offsetting the lessened demand). The new rate would then be above cost, but nevertheless might be justified. The New York Public Service Commission for the Second District justified the introduction of a telephone toll charge between the cities of Johnstown and Gloversville "as a means of regulating the trafie rather than as a revenue producer solely." ${ }^{14}$

In other cases, instead of overcrowding the service, the cornpany may either have to refuse to serve new applicants, or else have to ration its supply in some manner among all applicants, or in some manner extend its supply. Where the supply ean be increased as cheaply as it was originally produced, there is no problem; but where additions can be made only at a greater cost, it may be thought inexpedient or unjust to require the company to increase it. If rates were not regulated, the company would be likely under these conditions to increase its rates to the point where the excess demand is discouraged; it would lose nothing by destroying that part of the demand which it cannot meet. But by charging these higher prices, it might well be that it would receive more than a fair return. Yet in the case of a regulated utility that may be the best way out. This may well be another instance where social expediency may require the charging of a rate above cost. This is not true in all cases. Even private companies sometimes prefer to maintain a stable price policy even though it would be possible at times for them to raise their prices and still get all the orders they can fill. Frequently in the case of irrigation companies it is thought better to leep the rate down and then permit the customers to be served in some order of priority determined by the commission..$^{25}$ In the case of cars for the carriage of coal, our policy is to fix rates at which the demand for cars at some seasons exceeds the available supply. This gives rise to controversies as to the number to which each mine is entitled. ${ }^{16}$ The problem arises in the case of natural gas. ${ }^{17}$ It gave rise to the unsuccessful attempt of the legislature of West Virginia to accord priority to domestic consumers over those in other states. ${ }^{18}$ The problem of rationing was acute dur-

\footnotetext{
11 Edwards v. Glen Telephone Co., PUB. UTu. REP. (N. Y.) 1916 B, at $940,965$.

15 For a case of this kind see Ferrasci v. Empire Water Co., PUD. UTu. REP. (Calif.) $1915 \mathrm{~B}$, at 438, $447-448$.

16 See United States v. New River Co., 265 U. S. 533, 44 Sup. Ct. 610 (1924); Avent v. United States, 266 U. S. 127, 45 Sup. Ct. 34 (192d); Berwind-White Coal Mining Co. v. United States, 9 Fed. (2d) 420 (E. D. Pa. 1925); United States v. Koenig Coal Co., 46 Sup. Ct. 802 (1020); United States v. Mrichigan Portland Cement Co., 46 Sup. Ct. 305 (1020).

17 For an interesting discussion see (1918) 31 Hrrv. L. REv. 1025.

18 Pennsylvania v. West Virginia, 262 U. S. 553, 43 Sup. Ct. 653 (1923).
} 
ing the war, when prices of many commodities were fixed at a point sufficiently low to cause the demand greatly to exceed the supply..$^{19}$

While social expediency may dictate a cost rate in many cases even if that necessitates priority regulation, it does not necessarily dictate one in all cases. There is one case in particular in which the cost rate does not seem the best way out. When there are several railroads or several plants of any sort all furnishing parts of the total output of the same service, and all producing at different costs, a uniform rate for all the plants may be thought desirable. If we assume that the plants with the lower costs cannot increase their output except at costs equal to those of the most expensive, and that the outputs of the latter are essential, what would be the advantage of having different prices for each plant? Every buyer would then prefer to buy his supply at the low-cost plant. But its output is limited, and some of the buyers would have to buy elsewhere at a higher price. ${ }^{18 a}$ The benefit of the lower prices would be confined to those buyers who were permitted to buy at the low-cost plants. ${ }^{20}$ A uniform rate (sufficient to yield a fair return to the highest cost plant that we need to keep going) would equalize matters among the various classes of buyers. But it presents other problems.

These other problems arise whenever we have rates other than cost rates. Where rates above cost are fixed solely to offset rates below cost on other services rendered by the same company, the ground of social expediency dictating the higher rates is based on the desire to give the company the additional revenue resulting. In such a case, the fact that the company gets the additional revenue from these rates presents no problem. Conversely, when a service which cannot pay its way is nevertheless required for some reason of social policy, but where its requirement is justified only because the loss is offset by other rates which exceed cost, there is no problem. These two cases of rates above and below cost respectively do not result in the company receiving either more or less than the fair return that is justified by other considerations of policy. The matter is different, however, when

${ }^{19}$ At the time a very penetrating discussion of the problem appeared in the New Republic. Alvin Johnson, What Priority Means (June 30, 1917) vol. 11, p. 237.

19a If, however, the plants with the low costs can meet the demands of these buyers; we may have the situation already dealt with, where competitors might be ruined unless the low-cost plants charge the same rate as the high-cost ones.

20 In State ex rel. Sagness v. Hawk Creek Telephone Co., 120 Minn. 395, 139 N.W. 711 (1913), the relator was denied connection with one line of a local telephone company, which was already filled to capacity, but offered connection with another line from which he could obtain the samo service, but the rate for which (since it cost more) was higher. He was denied relief against the company. 
rates are fixed below cost because of failure to predict accurately the return to be derived from them, or when they are fired above cost because of inaccurate predictions in the opposite direetion, or when they are fixed above cost to avoid cut-throat competition, to avoid overcrowding the service, or to aroid the necessity of rationing the supply. Where the rates are fixed above or below cost because of erroneous predictions, there is no soeial purpose in the deviations from cost; the purpose of fixing the rates in question was to give the company what was adjudged to be its fair return. That purpose has been frustrated in part, due neither to the fault nor to the merit of the company or its officials.: There is no reason why the stockholders should suffer or tale advantage of the mistake. In case the rates turn out to be insufficient, it would seem only fair to permit the company either to add the loss to the rate base on which a fair return is to be calculated in the future, or else to amortize the loss out of rates for a number of years. This position was taken by the Michigan Commission in the case of Re City of South Haren.:= The same reasoning applies to gains made by the company above a fair return when the error was the other way. There is no reason why these gains should not be treated as a return of so much capital, and deducted from the rate base on which the fair return thereafter is to be calculated. ${ }^{3}$

In the above cases, the deviation of the rates from cost was temporary. In the other cases of rates fixed above cost for one or another ground of social policy, there was no error to be cured. The condition may go on indefinitely. The higher rate is promoting the purpose for which it was established-i.e., protecting the competitor, or discouraging the use of an overcrowded service, or acting as a selective device to discourage bids for the service which cannot be accepted. In none of the cases was the purpose to enrich the company, yet such is the incidental effect,

21 It is not intended to deny in this article the desirability of giving the company a chance to earn more if it succeeds in heeping down costs, and less if it fails. See, however, Chas. S. Mongan, Reguldtiun did timc MIanagenient of Public Ururtes (1923) 316-319. The limits above and below which that return could be allowed to go, however, might be stated, and rates yielding anything within that belt be decmed as inciuded in the term "fair return." Then what is stated in the text would apply only in case the yield of the rates turned out to be above or bolow thoce limits.

22 PUE. UTI. REP. (Mich.) $1923 \mathrm{E}$, at 694. A very persuasive plea for this policy is made by A. H. Ryall in The Principle of Reparation Applict to Rate Regulation (1925) 23 IIrCH. L. REv. 233.

23 Reserves for equalizing returns from year to year are also desirable for avoiding the necessity of a constant alteration of the rate base. See JoHN Bauer, Effective Regulation of Punlic Utilitics (1025) 296-205; and discussion of the proposition to establish such reserves by the California Commission in Re Southern California Edison Co., Pub. Uric. Rep. (Calif.) $1921 \mathrm{D}$, at $65,80-82$. 
unless some further action is taken. If some corrective can be adopted to remove this incidental effect without defeating the other purposes, that corrective cannot be said necessarily to be counter to grounds of social policy. The two correctives that suggest themselves are the reduction of the rates on other services rendered by the same company to less than cost, and the public appropriation of the surplus above the fair return.

We have seen that the receipt of rates above cost on some services has at times been treated by the Supreme Court as a circumstance which justifies the requirement of certain other services that cannot be rendered except at a loss. It is suggested that this might be carried further. If there are some services which can be rendered at cost rates, but whose cheapening would be of public advantage if not done at the unfair expense of anyone else, why should not some of these services be ordered to be cheapened, provided the loss is made up from other rates which will be kept up in any event, whether this cheapening is done or not? If this suggestion were carried through, the social purpose in maintaining some of the rates above cost would still be served, and only the incidental and unsought effect of giving the company more than a fair return would be avoided.

Would such a procedure be upheld by the Supreme Court? At first glance it seems to violate the doctrine of the North Dalioto case. Yet if the Court were to be convinced of the desirability of the action, it could be sustained without reversing that case. Justice Hughes's doctrine could be confined to the facts which very likely existed in the North Dakota case, and on the assumed existence of which he based his reasoning. "It does not aid the argument," he said, "to urge that the state may permit the carrier to make good its loss by charges for other transportation. If other rates are exorbitant, they may be reduced. Certainly, it could not be said that the carrier may be required to charge excessive rates to some in order that others might be served at a rate unreasonably low. That would be but arbitrary action." Note the assumption of this argument, that the rates on other services that yield more than a fair return are for that reason "exorbitant" or "excessive." That assumption is not always true. It was evidently thought not to be true by the Supreme Court itself in the Atlantic Coast Line, ${ }^{24}$ in the Puget Sound ${ }^{20}$ and in the Groesbeck ${ }^{26}$ cases, as we have already noted. It was thought not to be sound in the Dayton-Goose Creek ${ }^{27}$ case, to which we shall turn presently. It is also difficult to see why it is sound in

24 Supra note 6.

${ }^{25}$ Supra note 7.

${ }^{20}$ Supra note 9.

${ }_{27}$ Dayton-Goose Creek Ry. v. United States, 263 U. S. 456, 44 Sup. Ct. 169 (1924). 
the cases we are discussing, where a social purpose is promoted by fixing certain rates above cost. In the North Daliota case itself, it may very well have been a correct assumption. Nothing appears there to the contrary. Eut obviously the reasoning has no application where the carrier is permitted to make up its loss on the transportation of some goods by rates for other transportation that are not "exorbitant," but that nevertheless yield more than a fair return.

This solution of the problem may, however, be vetoed by future decisions of the court. And it can only be applied where there are classes of service whose rate can be reduced without encountering the same grounds of social policy that dictated the higher rates whose incidental excess earnings we are trying to distribute. The field for the application of this policy is therefore strictly limited. The other solution is the public appropriation of the surplus above the fair return. The Transportation Act of 1920 adopted this policy as to one-half of the surplus earnings. It was argued that this "recapture" provision was unconstitutional, partly on the ground that if a rate was fixed which was reasonable to the shipper, that rate must likewise be reasonable to the railroad in its yield, and consequently that to deprive it of the incidental earnings resulting was confiseatory. The opponents of the act failed to recognize that there might be grounds of social policy for making the shipper pay a higher rate, which did not make it essential for the railroad to keep the incidental proceeds. This distinction, however, was clearly reeognized in the opinion of the Supreme Court rendered in 1924 by Chief Justice Taft.2s That case established the constitutionality of the "recapture" method of dealing with the surplus earnings of a railroad which result from rates that are fixed for certain reasons of policy at a point higher than that required by those reasons of policy which are embodied in the formula, "fair return on fair value."

This procedure adds a new element to the conception of a "public utility." Hitherto, the principal burdens that could be laid upon "businesses affected with a public use," and not upon other businesses, were the requirements that all must be served (to the limit of the facilities), and served adequately, at rates which the legislature or a commission could establish (subject to court review) - the rates so established to be not exorbitant and not unduly discriminatory. The legal discussion of what sorts of business are "affected with a public use," although possibly confused and fumbling, has really centered on the underlying problem of what businesses would be in a position, if unregulated, to cause serious harm by refusing service, or by charging unduly

${ }^{28}$ Supra note 27. 
discriminatory or exorbitant prices. A business may be thought to require control in some of these respects but not in all. The state may control the rates of an insurance company, even though the company may refuse to insure any particular applicant..$^{\circ}$ Under the recapture provision of the Act of 1920, a railroad which is not offending in any of the conventional ways against which the power to regulate has been sustained, may nevertheless have such of its earnings as exceed six per cent on the "value" of its property, impressed with a trust for the benefit of the government. Such at least is the provision of the strtute. The Court does not preclude itself, in the Dayton-Goose Creek case, from holding in a particular case that the recapture is invalid if it leaves the company less than a "fair return" (rather than a rigid six per cent) on the "value."

Control of a business "affected with a public use" may include, then, control by "recapturing" excess earnings. May not the concept of property "affected with a public use" be gradually broadened to include such businesses as require this kind of control even when it would not be desirable to reduce the prices of their products? It is at least conceivable that when the courts take to analyzing the economic functioning of property rights, if they ever do take to analyzing it, they will find a wide field of such rights the economic yield of which might well go in part into the public treasury by "recapture." Taxation would then be applied to many forms of property in which the conventional canons of the tax writers will be discarded. Instend of those canons, the question will be asked, not what proportion of the net income should be taken, but by how much does the net income exceed a fair return on the "fair value" of the property (the "fair value" being determined as in a rate case). Then the balance over the fair return will be appropriated, in great part, by the government.

But without any conscious use of the concept of "public utility," we have already used for a short time a form of taxation which applied somewhat similar principles-namely, the "excess profits tax." In administering that tax, it became essential to define what the "investment" was, eight per cent of which was exempt from the tax. It was argued that the company was entitled to deduct eight per cent on the "value" of its capital assets, not merely on their cost. This was in a case where the original cost was very much the lower figure. It was further argued that unless the exemption in the statute be interpreted as applying to value rather than cost, the statute was unconstitutional. The Supreme Court decided against the company on both points in

${ }^{20}$ German Alliance Ins. Co. v. Lewis, 233 U. S. 389, 34 Sup. Ct. 612 (1914). 
La Belle Iron Works v. United States: ${ }^{\circ} \quad$ Yet if the Court applies the recapture principle, and extends it, while it will be administering substantially the same tax, it will most lilkely hold that what is subject to recapture is the excess above a fair return on the "rate-making valuation." If the clause were specifically amended to specify "fair return on the actual cost" instead of "six per cent on the value," a recapture which left the company little more than a fair return on cost would be held invalia in case the rate making "value" were substantially greater. The Court has often enough and clearly enough expressed its opinion that the "value" on which rates must be permitted to yield a fair return is not actual cost, although what that "value" is or can be, consistent with the state's power to reduce net earnings at all, no mortal man may know. An extension of the recapture principle, then, if viewed through the rate-making lens, would limit the principle in such a way that the company might be constitutionally protected in keeping much more than a fair return on cost; if viewed through the lens of the La Bclle Iron case, the company would be accorded protection of no more than a fair return on cost. Whether the attempt to focus both lenses on the same object may some day lead some judicial aculist to attempt to straighten the Court's vision on the valuation problem remains to be seen.

${ }^{30} 256$ U. S. 377,41 Sup. Ct. $52 S$ (1921). 